\title{
Pontus Sorunu: Tarihi Seyri ve Çözüm Çalışmaları
}

\author{
Mustafa Yahya METiNTAŞ, Mehmet KAYIRAN*
}

Pontus Sorunu: Tarihi Seyri ve Çözüm Çalışmaları

Özet

Pontus Sorunu, 19. Yüzyılın ortalarında Yunan bağımsızlık hareketiyle ortaya çıkmış ve Megalo İdea'nın bir uzantısı olarak Doğu Karadeniz kıyılarında Pontus adı altında bir Yunan - Rum devleti kurulması amacı çerçevesinde gelişmiştir. Pontus Sorunu, I. Dünya Savaşı sırasında olgunlaşarak hem siyasi hem de çete faaliyetleri yönünden belirginlik kazanmış, silahlı bir isyana dönüşmüştür. Ankara'da kurulan TBMM Hükümeti, 1920 yılı başlarından itibaren bir yandan Milli Mücadeleyi sürdürürken diğer taraftan da Pontus Sorunu ile uğraşmak ve ciddi tedbirler almak zorunda kalmıştır. Milli Mücadele sonrasında Pontus Sorunu Lozan Konferansı'nda tartışımış ve alınan kararlar gereği Türk ve Rum ahalinin mübadele edilmesi ile çözüme kavuşturulmuştur. Siyasi, tarihi ve kültürel sonuçları ile Pontus Sorunu günümüzde de etkisini devam ettirmekte olup, Türkiye'nin gelecek politikaları için ders verici özellikler taşımaktadır.

Anahtar Kelimeler: Pontus Sorunu, Milli Mücadele, Türkiye Büyük Millet Meclisi
Pontus Problem: Historical View and Solution Studies

Abstract

The problem of Pontus has emerged in the middle of $19^{\text {th }}$ century through the Greek independence movement and has been developed within the framework of the aim of establishing a Greek-Roman state in eastern Black sea coastline. The Pontus problem has developed during the First World War with becoming evident in terms of both politics and gang acts, and has turned into an armed uprising. The government of Turkish National Assembly, established in Ankara in the beginning of 1920 , had to deal with the problem of Pontus and to take serious measures while trying to sustain the National Struggle. After the National Struggle, Pontus problem has been discussed in Lausanne Conference and the problem has been resolved by the exchange of Turkish and Greek population. The political, historical and cultural outcomes of Pontus problem are still present in the present day and has lecturing characteristics in terms of future political course of the Turkey.

Key Words: Pontus Problem, National Struggle, Turkish National Assmebly

\section{Giriş - Pontus Halkının Kökeni}

Pontus veya Pontos kelimesi etnik bir isim değil coğrafi bir tabirdir. Pontus veya Pont - Euksinos (Konuksever Deniz) eski Yunanlıların Karadeniz'e verdikleri bir isimdir. Buradaki Euksinos İrani "Ahşeana" kelimesinden gelmektedir ve konuksever anlamı taşımaktadır (Güzel, 2006, s. 17). Celal Esad Arseven, Karadeniz kıyılarını Yunanlılardan önce keşfeden Fenikelilerin bu denize "Şimal Denizi" manasında "Achkenos" dediklerini ve Yunanlıların bunu Euksinos'a dönüştürdüklerini belirtir (ss. 26-75). Bu nedenle "Konuksever Deniz"- Rumca Pontus Euksinos - terminolojisi Yunanlılara ait değildir.

Mustafa Yahya METiNTAŞ, Yrd. Doç. Dr. ESOGU Fen - Edebiyat Fakültesi, Tarih Bölümü, mmetintas@hotmail.com; Mehmet KAYIRAN, Yrd. Doç. Dr., ESOGU Fen - Edebiyat Fakültesi, Tarih Bölümü, Mkayi@ogu.edu.tr 
Pontus adı genellikle Doğu Karadeniz sahilleri için kullanılmakla birlikte, kapsadığı alan zaman zaman değişiklik göstermiştir. Yeşilırmak, Kızıırmak ve Kelkit Havzası Pontus sayıldığı gibi, bu alan daha da genişleyerek Doğu'da Kafkasya'dan bütün Karadeniz kıyıları boyunca Sinop ve ötesine kadar uzanmıştır (Sarınay, 1999; Yazıcı, 2003). 1918 Kasım'ında, bölgede Pontus idealini oluşturan ve sürdüren cemiyetler tarafından Pontus'un ulusal istekleri konusunda büyük devletlere verilen notada, sınırlar şöyle belirtilmiştir: “Doğuda Batum, güneyde Ermenistan ve batıda Sinop'un batısına kadar uzanan muhteşem Pontus Eyaleti" (Türk İstiklal Harbi, 4. Cilt, 1975, s. 284). İstanbul'da yayınlanan Patris Rum Gazetesi'nin 17 Ocak 1919'daki bir yazısına göre, hayali Pontus Devleti'nin sınırları şu bölgeleri içine almaktadır: Trabzon, Giresun, Ordu, Samsun, Sinop, Gümüşhane, Şarki Karahisar, Tokat, Amasya, Çorum, Yozgat Sancaklarının tamamı, Erzurum Vilayeti'nin İspir ve Bayburt kazaları, Erzincan Sancağı'nın Refahiye ve Kuruçay kazalarının tamamı, Sivas Vilayeti ile Koçgiri, Yenihan, Hafik kazaları kısmen, Kastamonu Vilayeti'nin Tosya, Taşköprü kazalarının tamamı, kısmen İnebolu kazası. Bu hayali devletin başkenti olarak da Samsun gösterilmekte ve yüzölçümü 70.000 kilometre kare olarak kabul edilmektedir (Güzel, 2006, s. 20). Mahmut Goloğlu'nun Fransız bilim adamlarının yaptıkları çalışmalara dayanarak belirttiğine göre, Doğu Karadeniz Bölgesi'nde ilk yerleşim yerleri ticaret amacı ile Asurlular tarafından kurulmuştur. Yine Goloğlu'na göre Pontus Krallığı'nın kurulduğu dönemde bölgede oturmakta olan halk üç bölümden müteşekkildir. Bunlar İranlılar, kıyı şehirlerinde Yunanlılar ve bölgenin asıl yerli halkı olan Turanlılardır (Goloğlu, 1973, s. 78).

Pontus bölgesine tarihi süreç içerinden yerleşen halklar ve kökenleri ile ilgili çeşitli fikirler mevcuttur bunlara göre, Türklerin yaşadığı yerler de dâhil olmak üzere Anadolu ve çevresindeki topraklardan; Kaşkalar, Hurriler, Kolhlar, Kaldiler, Masklar, Tibarenler, Marlar, İskitler, Driller, Amazonlar ve Kimmerler bu bölgeye tarihin çeşitli dönemlerinde yerleşmişlerdir. Bunlardan Kaşkalar, Hurriler, İskitler ve Kimmerler bugün araştırmacılar tarafından Türklerin ataları olan Proto Türkler olarak nitelendirilmektedirler (Yılmaz, 2010, ss. 11 - 16). Gürcü kökenli bilim adamlarına göre, bölge halkının kökenleri Gürcülere dayanmaktadır. Bu araştırmacılara göre tarihi Pontus bölgesinde konuşulan dil, Yunan dilinin özelliklerini göstermeyip, İbero Kafkas dillerinin Kartvelien gruplarının özelliklerini yansıtıyor ve bu dil Gürcü diline has nitelikler taşıyor. Yine Gürcü Bilim adamlarına göre, bölge için kullanılan Lazistan ismi Gürcü dilindeki “Ça'neti” isminden gelmektedir (Yılmaz, 2010, ss. 11 16).

Tarihi Pontus Krallığı MÖ 301 yılında Pers kökenli Mithridates sülalesi tarafından kurulmuştur. MÖ 301 - 63 yılları arasında yaşayan bu krallık, yaşadığı çağ boyunca Doğu'da Roma İmparatorluğu'na rakip olabilecek bir güce erişmiştir. VI. Mithridates zamanında Pontus Krallığı'nın sınırları Ege Denizine kadar ulaşmıştır (Gedikli, 2002, ss. 17 - 18). Pontus Krallığı'nın hem kurucusunun hem yöneticilerinin hem de tebasının Yunanlılarla bir ilgisi yoktur. Pers kökenli Mithridates sülalesi genelde yerli Anadolu kültürü ile Anadolu'nun bağımsızlığı mücadelesini yürütmüştür (Yazıcı, 2003, s. 28). Pontus orduları MÖ 66'da Romalılar tarafından bozguna uğratılmış ve krallık MÖ 63'de tamamen ortadan kaldırıımıştır (Yazıcı, 2003, s. 29). Bölge halkı Roma hâkimiyeti sırasında Hıristiyanlığın 
ortaya çıkışı ile birlikte Hıristiyanlaşmaya başlamıştır. 13. Yüzyılda Bizans (Doğu Roma) merkezi idaresinin zayıflaması üzerine Doğu Karadeniz Bölgesinde Trabzon merkezli Trabzon Devleti (1207 - 1461) kurulmuştur. Trabzon Devleti'nin kurucusu İstanbul'un Latinler tarafından ele geçirilmesi üzerine İstanbul'dan kaçan Kommenos ailesinden Prens Aleksios Kommenos'tur. Aleksios Kommenos gürcü Kraliçesi Tamarra'nın da desteği ile Trabzon'da kendini kral ilan etmiştir (Yılmaz, 2010, s. 20). Trabzon merkezli bu küçük krallığın daha önce kurulan Pontus Krallığı ile bir ilgisi yoktur.

Selçuklular döneminde Sinop'un Türkler tarafından ele geçirilmesi ve Trabzon'un kuşatılmasıyla Türkler ve Trabzon Devleti arasında ilk mücadeleler başladı. Daha sonra bu devlet, Türklere ve Moğollara vergi vererek varlığını sürdürebildi. Uzun Hasan'la anlaşan Trabzon Krallı̆̆ı'na, Fatih Sultan Mehmet tarafından 1461 yılında son verildi.

\section{Pontus Sorunu'nun Ortaya Çıkışı: (1908-1918)}

Osmanlı İmparatorluğu içindeki Pontusçu faaliyetler 1908'den itibaren hissedilir derecede artmıştır. Bunun sebebi, Rum azınlığın 19. Yüzyılın sonlarından itibaren devam eden teşkilatlanma çabalarının artık meyvelerini vermeye başlaması olduğu kadar, 1908 i̇kinci Meşrutiyet düzenlemelerinin ülkedeki tüm azınlıklara olduğu gibi Rumlara da geniş bir örgütlenme ve propaganda özgürlüğü getirmesidir (Okyar, 1980, s. 95). Nitekim Avrupalı büyük devletlerin sınırsız desteği ve Yunanistan'ın “Megali İdea” planı doğrultusunda yaptığı propagandanın yönlendirmesi ile hareket eden Osmanlı Rumları, kısa süre içinde Anadolu'da büyük bir siyasi ve askeri krize dönüşecek olan “Pontus Sorunu" nun temellerini atmaya elde ettikleri yeni haklar sayesinde hız vermişlerdir.

Fatih Sultan Mehmet'in İstanbul'u fethettikten sonra tanıdığı ayrıcalıklar sayesinde varlığını sürdürebilen İstanbul'daki Rum Patrikhanesi, Pontusçu faaliyetlerin ülke genelindeki organizasyonunu üstlenmiştir (Arşiv Belgeleriyle Rum Faaliyetleri, Cilt 1, 2009, s. 132). 20 Yüzyılın başlarında Pontusçu faaliyetler genellikle iki fikir çerçevesinde şekillenmiştir (Bayar, 1967). 1910 yılına kadar faaliyetlerin stratejisini "kilise hiyerarşisinin etrafında ve Ortodoks Patriği'nin kontrolü altında Bizans İmparatorluğu'nun tekrar kurulması fikri belirlemiştir." 1910 yılından itibaren ise Yunanistan'da iktidara gelen Venizelos'un ortaya attığı bir hedef olan Ege Denizi merkez olmak üzere iki kıta ve beş denize yayılacak bir "Büyük Yunan - Bizans İmparatorluğu” fikri Osmanlı Rumlarının Pontusçu faaliyetlerinin çerçevesini çizmiştir (Yılmaz, 2010, s. 59).

Yunanistan'ın ve Rum Patrikhanesi'nin faaliyetlerinin yanında, Osmanlı ülkesinde yaşayan Rum azınlığın ticaret sayesinde iyice zenginleşmesi, buna bağı olarak artan refahın siyasi bilinçlenme getirmesi Anadolu'da Pontusçu propagandanın karşılık bulacağı bir toplumsal zemin yaratmıştır (Yerasimos, s. 35). Kısa süre içerisinde Yunanistan'ın desteği ve yönlendirmesi ile Rize'den İstanbul Boğazına kadar olan bölgede ve bunun bir kısım güneyinde eski Yunanlıı̆ı̆ın canlandırılması için çalışan bir teşkilat ortaya çıkmıştır. Amerikan Rum göçmenlerinden Rahip Klematyos ilk toplantı yerini İnebolu'da halkın “Manastır” diye andığı bir tepede kurmuştur (Sertoğlu, 1982, s. 546 - 565). Bu teşkilat mensupları zaman zaman dağınık eşkiya çeteleri halinde faaliyet gösteriyorlardı. Birinci Dünya Savaşı sırasında dışarıdan gönderilip dağıtılan tüfek, cephane, bomba ve makineli tüfeklerle 
Samsun, Çarşamba, Bafra ve Erbaa rum köyleri adeta bierr silah deposu haline gelmişlerdi. (Nutuk, Cilt 2, 1973, s. 626). Pontus teşkilatının temelinin 1904 yılında Merzifon'daki Amerikan Kolejinde atıldı̆̆ı bilinmektedir. Bu Kolej aslında 1860 yıında İstanbul'da açılmış olmakla birlikte misyonerlik faaliyetleri için 1884 yıında Merzifon'a taşınmıştır. 1921 yıında Koleje yapılan baskın sonucu ele geçirilen belgelerden Pontus teşkilatının merkezinin burası olduğu anlaşılmıştır. Baskın sırasında ele geçirilen belgelere göre, Kolej bünyesinde öğrenci ve personel olarak bulunan 149 kişi Pontus hedefi doğrultusunda çalışmalar yürüten Pontus Cemiyeti, İrfanperver Kulübü, Pontus İdman Kulübü gibi kuruluşlarda çalışmışlardır. Kolej, 1921 yılındaki baskına kadar binden fazla Rum gencini Pontus ideali doğrultusunda yetiştirmiştir (Güler, 1988, s. 49).

1908 yilında Samsun'da "Müdafaa-i Meşrute", daha sonra da "Mukaddes Anadolu Rum" cemiyetlerinin kuruluşu ile Pontus teşkilatlanması genişletilmiştir (Sarınay, 1999, s. 6). Osmanlı Devleti’ndeki Pontus teşkilatı 1909 yılında Atina'da kurulan “Asya-i Suğra Cemiyeti”nin kontrolü altına girmiştir. Pontus Cemiyeti ilk kapsamlı propaganda bildirisini 1910 yılında yayınlamış ardından bildiride belirtildiği üzere Batum'dan İnebolu'ya kadar olan tüm Karadeniz coğrafyasında teşkilatlanma işine girişilmiştir (Tansel, 1991, s. 91). Pontus Cemiyeti'nin amacı Trabzon, Ordu, Samsun, Giresun sahil vilayetleri ile Kastamonu, Gümüşhane, Erzincan ve Sivas vilayetlerinin bir kısmını içine alan bölgede, daha sonra Yunanistan ile birleşecek bir Pontus Devleti kurmaktı.

\subsection{Cemiyetler}

Pontus Derneği 1904 yılında Merzifon Amerikan Koleji'nde gizli olarak kurulmuş ve onu, 1908'de Samsun'da Müdafaa-i Meşrute ve daha sonra Kutsal Anadolu Rum Dernekleri izlemiştir. Müdafaa-i Meşrute Derneği bütün Anadolu'yu içine alan silahlanmış bir örgüt meydana getirmekle görevliydi. Bu derneğin Samsun Metropolithanesi'nde elde edilen tüzüğüne göre: Ünye, Fatsa, Kırşehir, Kavak, İnebolu, Havza, Çarşamba, Bafra, Sinop, Kayseri, Ürgüp ve Tokat'ta şubeleri vardı (Esegin, 1969, s. 196). Yaşı 20’nin üzerinde olan her erkeğe silah dağıtılmıştı. Mukaddes Anadolu Rum Cemiyeti, bu derneğe para toplamak, örgüte girmeyen veya yardım etmeyenleri korkutmak ve yurt dışı ile haberleşmede bulunmak amacıyla kurulmuştu (Türk İstiklal Harbi, s. 282).

Osmanlı Rumlarının Pontus Devleti'nin kurulması yönünde gerçekleştirdikleri teşkilatlanma çabaları 1918'de Mondros Mütarekesi'nin imzalanmasının ardından daha da hızlanmıştır. Rumlar bu dönemde değişik isimler ve görev tanımları altında pek çok yeni cemiyet kurmuşlardır. Bunların başlıcaları ve üstlendikleri görevler şöyledir (Pontus Meselesi, ss. 30-44):

1. Rum Matbuat Cemiyeti: Ermeni ve Rum suçluların tahliyesine çalışacaktı.

2. ̇̇zci Teşkilatı: Rum gençlerin askerlik sanatını öğrenmesini sağlayacaktı.

3. Müdafaa-i Milliye Teşkilatı: Rum cemiyetlerinin faaliyetlerini ortak kılmaya çalışacaktı.

4. Rum Trakya Cemiyeti: Hazırladıkları gerçek dışı istatistiklerle propaganda yapacak ve Rum nüfusu silahlandıracaktı. 
5. Rum Muhacirin Cemiyeti: Muhacirlerin ilgili bölgelere yerleştirilip, mülk edinmeleri için uğraşacaktı.

6. Rum Cemiyeti Ticariyesi: Müslüman tüccara zarar verecek, onları iflasa sürükleyecek ve Yunan mallarının ithalatını yaygınlaştırmaya çalışacaktı.

Son derece faal olan bu cemiyetlere ek olarak gerek bu cemiyetlerin gerekse İstanbul Rum Patrikhanesi'nin programından ayrılmayan; mali bakımdan da bu merkezlerden ve Rum nüfustan yardım alan çeşitli teşkilatlar kurulmuştur: "Pontus İdman Kulübü”, "Iirfanperverler Kulübü”, "Müdafaa-i Meşrute Cemiyeti”, “Mukaddes Anadolu Rum Cemiyeti”, "Rum Teceddüt ve İhya Cemiyeti” sayılabilecek başıca faal teşkilatlardır. Osmanlı Devleti sınıları içinde Pontusçu Rumlar tarafından kurulan bu cemiyetler sadece kendi hedefleri için değil, kuruldukları andan itibaren müttefik menfaatleri için de çalışmışlardır. "İ̧̧galciler için casusluk yapma, Türk halkının mukavemetini kıracak propaganda faaliyetleri, yabancı müdahalesini teşvik etmek için mahalli asayişi bozuk göstermek" gibi faaliyetleri bunlara örnek verilebilir (Nutuk, 627).

\subsection{Dış Destek}

Pontusçu faaliyetlerin ortaya çıkışında ve gelişiminde Amerikalı misyonerlerin önemli rolleri olmuştur. Amerikalıların Rumlara ilgisi, Helencilik akımının yaygınlaşması ve 1828'de Amerika'da, Yunan İsyanı nedeni ile Rumlara yardım amacıyla "New Heaven Ladies Greek Asocation"un kurulmasıyla atılmıştır. (Yılmaz, 2010, s. 61) Amerikalı misyonerler 1831'de İstanbul ve 1834 'de İzmir'de ilk merkezlerini açtıktan sonra Bursa ve Trabzon şubelerinin de kurulmasıyla çalışmalarını yaygınlaştırmışlardır. 1904'te Merzifon'da açılan Amerikan Misyoner Koleji de isyanın yönetildiği yer olmuştur (Çiçek, 1999, s. 199). Karadeniz bölgesinde misyonerlik faaliyetleri aynı tarihlerde başlamış, bu tarihten sonra çok sayıda gayrimüslim okulu açılmıştır. Trabzon'da 3 Amerikan, 5 Fransız; Sivas'ta 3 Amerikan, 4 Fransız ve Kastamonu'da 2 Fransız olmak üzere 17 yabancı misyoner okulu faaliyete geçmiştir (Gülbadi, 2008, s. 202).

Pontus faaliyetleri en yoğun biçimde Yunanistan tarafından desteklenmiştir (Arşiv Belgeleriyle Rum Faaliyetleri, 2009, s. 144 ). 1914 yılı öncesi Pontus ile ilgili cemiyetlerin faaliyetleri daha çok Batum merkezi ağırıklıydı. Ancak 1914 yıllarından itiaberen ilgili devletlerin himayesi ile faaliyetlerin merkezi daha çok Atina'ya kaydırıldı. Bu durum Türk makamlarınca da yakından izlenmekte, faaliyetlerin Atina'da yoğunlaşmasının yavaş yavaş örgütlü çeteleşmeye dönüşeceği beklenmekte, bu durumdan daha çok Fransa sorumlu tutulmaktaydı (BCA, 250, 690, 5). Pontuscular Yunanistan'da ve bu ülkenin etki alanında çok güçlü biçimde faaliyet göstermişlerdir. Bilhassa Venizelos'un Yunanistan'da başbakan olarak göreve başlaması sonrasında Yunanistan yayılmacı hedefleri çerçevesinde Osmanlı Devleti dâhilindeki Rumları yoğun propagandalar ile kışkırtmış ve isyancı faaliyetlere teşvik etmiştir. Yunanlıların Anadolu'daki Türk varlığını hedef alan yıkıcı ve bölücü faaliyetleri Osmanlı Devleti'nin son bulmasına kadar kesintisiz bir şekilde devam etmiştir.

Pontusçu faaliyetler, Birinci Dünya Savaşı yıllarında Rusya, Yunanistan, Avrupa ve Amerika'da daha da hız kazanmış ve uluslararası bir boyuta ulaşmıştır. Örneğin 5 Mayıs 1917'de Tiflis'te "Yunanistan Kafkaslar Kongresi" toplanmıştır. Bir başka konferans, Karadenizin kıyı şehirlerinde yaşayan 
Mustafa Yahya METiNTAŞ | Mehmet KAYIRAN

Rumların temsilcileri ile 1917 Ekim ayı ortalarında Atina'da düzenlenmiştir (Güzel, 2006, s. 67). Bu dönem faaliyetlerindeki temel amaç Karadeniz kıyılarında yaşayan bütün Rumları bağımsız bir devlet çatısı altında birleştirmekti. Yine 1917'de Paris'te "Pontus Milli Merkezi" kurulmuş, ayrıca ABD'de aynı amaçla özel bir komite oluşturulmuştur (BOA, DH. KMSi D: 49-2, V: 24-3). Eylül 1917 tarihinden itibaren de Paris'te Fransızca olarak "Journal Des Hellenes" ve "Mediterranee Orientale" Londra'da "Esperia" ve Atina'da yayınlanan çeşitli gazete ve bültenlerle, yoğun bir propaganda başlatılmıştır.

Yunanistan' dan sonra Pontus faaliyetlerinin belki de en önemli destekçisi ülke Rusya olmuştur. Rusya Pontusçu örgütlenmenin kurulup güçlenmesinde ve silahlı çetelerin teşkilinde önemli bir rol oynamıştır. Rusya pek çok Pontusçu örgüt ve çete liderinin eğitilmesinde, bunların sahte pasaportlar ile Osmanlı topraklarına sokulmasında aktif rol oynamıştır. Rusya'nın faaliyetleri özellikle Birinci Dünya Savaşı yıllarında doruk noktasına ulaşmıştır. Bu konuda bir örnek vermek gerekirse Rusların 1916'da Doğu Karadeniz bölgesinde başarıyla ilerlemeleri bu bölgedeki Pontusçu faaliyetlerin yükseliş göstermesine yol açmıştır. Bizzat Rusya tarafında silahlandıılan Vasil Usta ve Dimitros Hasalanbidis çeteleri Rus ordusu ile birlikte bölgede terör estirmişlerdir (TBMM Gizli Celse Zabıtları, Cilt: 3, 1985, s. 665). Rusların 1916'da Trabzon'u işgal etmeleri üzerine şehrin yönetimini Vali Cemal Azmi Bey'den devralan Trabzon Rum Metropoliti Hırisantos, Ruslardan elde ettiği silahlar ile bölgedeki Rum çetelerini donatmıştır (Özel, 1991, s. 32).

Mondros Mütarekesi'nden önce Pontus'la ilgili en önemli kongre, 4 Şubat 1918'de Konstantin Konstantinides tarafından Marsilya'da yapılmıştır (Pehlivanlı, 1999, s. 91). Konstantinides Kongrede yaptığı konuşmada, Pontus'çuların özgürlüklerine kavuşmak için çaba harcadıklarını belirtmiş ve onların faaliyetlerini, propaganda araçlarını, Pontus Devleti'nin sınırlarını, tarihsel geçmişini ve hatta Pontus Bölgesi'nin Türk ve Hıristiyan halkının nüfusunu da vermiştir. Bu eyalet ulusların kendi geleceklerini belirleme ilkesine dayanacak, müttefik kuvvetler ve $A B D$, eski Trabzon İmparatorluğu'nu yeniden kuracak ve özerk bir cumhuriyet konumuna getirilecektir. Bu kongreden kısa süre sonra Temmuz 1918'de Pontus'un bağımsızlığının ve Birinci Dünya Savaşı'nda Kafkaslara giden Rumların eski vatanlarına dönme arzularının dile getirildiği bir Pontus Kongresi Batum'da toplanmıştır. Kongre sonunda, Ekim 1918'de Batum'da Pontus Ulusal Merkezi kurulmuştur (ATASE, KLS: 198, DS: 101, FH: 85). Pontusçu faaliyetler için çok önemli bir merkez olan Batum'da 15 Ocak 1919'da Pontus Rumları Derneği adıyla yeni bir dernek kurulmuştur. Dernek 16 Ocak 1919 günü yaptığı toplantıda İstanbul'da bulunan Yunan Yüksek Komiserinden ve Fener Rum Patrikhanesinden Pontus'un bir başka devletin yani Ermenistan'ın egemenliği altına girmek zorunda kalmadan özgürlüğüne kavuşabilmesi için izlenmesi gereken politika hakkında direktiflerin sorulmasına karar vermiştir (Yerasimos, s. 49).

Bu gelişmeler göstermektedir ki Mondros Mütarekesi imzalandığı zaman Türkiye dışındaki Pontus organizasyonu büyük ölçüde tamamlanmıştır. 


\section{3. Çete Faaliyetleri}

Pontus imparatorluğu kurmak rüyasına kapılan Rumlar, siyasi faaliyetleri yanında Anadolu'da yer yer çeteler kurarak Türk köylerini basmaya, kitle halinde cinayetler işlemeye ve soygunculuğa, ırz ve namusa tecavüze başlamışlardı (Türk İstiklal Harbi, C. VIII, s. 32). Birinci Dünya Savaşı́nın ilk önemli Rum çetecilik faaliyetleri Bafra'da ortaya çıkmış, bu faaliyetlerde ilk yapılan vahşetler Kasnakçı Mermer ve Çağşur Köylerini yakmak, halklarını da kadın, çocuk, yaşlı demeden öldürmek olmuştur (Türk İstiklal Harbi, s. 286).

Pontusçcu ideallere yönelik ilk silahlı organize Rum çetesi ise 1908 yılında Amasya Metropoliti olan ancak o dönem Pontus Teşkilatlanması tarafından Samsun bölgesi sorumlusu olarak görevlendirilen Germanos Karavangelis tarafından Samsun - Kadıköy Bölgesinde kurulmuştur. Stefanos Yerasimos'a göre Metropolit Germanos bölgede Yunan politikalarının uygulayıcısı bir figür olarak ön plana çıkmıştır. O, Yunanistan'ın “Osmanlı Devleti ile Balkanlarda yeni kurulan devletlerde yaşayan tüm Rumların Yunan bayrağı altında birleştirilmesi” politikasını benimsemiştir. Germanos'un kurduğu çete Yunan ticaret gemileri tarafından bölgeye gizlice taşınan silah ve cephane ile donatılmıştır (Sarınay, 1999, s. 68).

1908 yılında Samsun - Kadıköy'de ilk adımları atılan Pontusçu silahlı örgütlenme Balkan Savaşı'nın başlaması ile birlikte güç kazanmaya başlamıştır. Osmanlı Devleti'nin savaş nedeni ile seferberlik ilan etmesi ve uyguladığı seferberlik politikası Rumlar tarafından tepki ile karşılanmıştır. Askere alınan Rum gençleri kitleler halinde firar etmiştir. Askerden kaçanlar köylerine döndüler ancak normal yaşamlarını devam ettirmeleri mümkün olmadığından köylerine yakın kırlık alanlarda üstlendiler. Bu gençler kısa süre sonra bölgede gelişecek güçlü Rum çetelerinin insan gücünü oluşturdular. Balkan Savaşları sonunda Osmanlı Devleti'nin göçmen Türkleri Anadolu'da iskân etmesi sorunuda Rum ahalinin taşkınlıklarının artmasına yol açmıştır (Yerasimos, s. 36).

Birinci Dünya Savaşı́nın başlangııına kadar Pontus Rum Devleti'nin kurulması bir fikir halinde iken ve nispeten cılız çabalar şeklinde sürerken savaş ile birlikte ilk defa Rusya'nın ve Rusya'daki Yunan siyasi memurlarının girişimleriyle büyük bir ivme kazanmıştır. Batum ve Kafkasya'daki Rum tüccarları vasıtası ile Trabzon ve Samsun'daki merkezlerle haberleşilmiş, Batum'da teşkil edilen gizli bir komite ile gizlice silah ve cephane gönderilerek yöre Rumlarının faaliyetlerinin bir kat daha arttırılmasına çalışıımışı (TBMM Gizli Celse Zabıtları, c. III, s: 665). Anlaşma Devletleri, Birinci Dünya Savaşı başladığında Rumları özellikle kıyı şeridindeki Hıristiyanları kışkırtmış, kendilerine her türlü yardımda bulunmuşlardı (Yılmaz, 2010, s. 69). Seferberlik emrine karşı çıkan veya askerden kaçan Rumların kurduğu Pontus çeteleri, Karadeniz Bölgesi'nin her yerinde Türk ve İslam halka işkenceler yaparken cephe gerisinde de Osmanlı Ordusuna büyük zararlar vermişlerdir. Bir örnek vermek gerekirse Bafra'nın Bünyan Dağı civarında bulunan 11 Rum köyü 1,500 kişilik büyük bir çete oluşturmuştur. Bu çete, Osmanlı Devleti'nin bölgede devlet otoritesini yeniden sağlamak ve Rum çetelerini dağıtmak amacıyla bölgeye müdahalesine rağmen varlığını korumayı başarmıştır. Bünyan Dağı'na yerleşen Rum çetesi ancak Milli Mücadele sırasında uzun uğraşlar neticesinde ortadan kaldırılabilmiştir (Özel, 1991, s. 33). Rum çetelerinin diğer hedefleri Türkiye'yi zayıf düşürmek, üzer- 
Mustafa Yahya METiNTAŞ | Mehmet KAYIRAN

lerine kuvvet çekerek düşmana dolaylı destek sağlamak, Türk Ordusunu arkadan vurmak ve nihayet bölgedeki Rum varlığını ispatlayarak Türkiye'nin yenilmesi halinde Pontus emellerini gerçekleştirmekti. Rusya'daki Rumlarla Anadolulu Rusya'ya göç etmiş Rumlar Kafkasya ve Batum'da toplanmışlar ve Rum ordusunda yetişmiş Rum asıllı subaylardan General Anonya komutasında bir tümen oluşturmuşlardı. Bir Pontus hükümetinin kurulması için Trabzon ve yöresine çıkarılacak olan bu tümen Bolşeviklerin Kafkasya'yı işgalleri üzerine dağılmak zorunda kalmış, ancak geriye kalanlar Türk topraklarına geçerek Türkiye içinde faaliyet gösteren çetelere katılmışlardı.

Osmanlı Devleti'nin müfettişlerinin raporlarına göre Samsun bölgesinde 11, Bafra bölgesinde 5, Çarşamba Bölgesinde 8, Terme ve Ünye bölgesinde 3, Sinop bölgesinde 3 olmak üzere 30 Rum çetesi Ünye'den Sinop'a kadar faaliyet halindedir (Pontus Meselesi, ss. 71 - 108 - 109). 1916'da Pontusçu çetelerle mücadele için iki tedbir alınmıştır: Rum çetelerini dağıtmak ve Çetelerin destekçisi durumundaki Rum halkı bölgeden ülkenin iç kesimlerine nakletmek. 16 Kasım 1916’da Tirebolu Rumları Şarki Karahisar ve Suşehri arasında bulunan boşaltılmış Ermeni köylerine yerleştirilmiştir. 1917'de Samsun'dan 4,000 Rum Çorum'a Giresun Rumları iç bölgelere taşınmıştır. Bafra, Çarşamba ve Ünye'den 30,000 Rum Ankara'ya doğru yola çıkarılmış; 1917'de Ordu ve Sinop Rumları'da iç bölgelere nakledilmiştir. Nakledilen Rumlar 1918'de eski yerlerine dönmüşlerdir (Beyoğlu, s. 366).

\subsection{Merzifon Amerikan Koleji}

Daha önce ifade ettiğimiz gibi Pontusçu mücadelenin merkezi Merzifon Amerikan Kolejiydi. Kolejin faaliyet gösterdiği Merzifon Kazası, Amasya Sancağına bağlı idi ve Samsun'u (Canik Sancağı) İç Anadolu'ya bağlayan yol üzerinde bulunuyordu. Kolej aslında 1860 yılında İstanbul'da faaliyetlerine başlamış olmakla birlikte 1865 tarihinde Merzifon'a taşınmıştı. Kolejin taşınmasının sebebi Osmanlı Devleti'nin siyasi denetiminden uzaklaşmak istemesinin yanı sıra Amasya, Tokat, Sivas, Yozgat ve Kayseri'deki orta dereceli Amerikan misyoner okullarının öğretmen ihtiyacının karşılanmak istenmesiydi. Amerikan misyonerlerinin teşebbüsüyle Merzifon Kazası'nın kuzeyinde bir kısım arazi ve tarlalar satın alınmıştı. Buralarda inşaata başlanarak kısa zamanda ev, okul, aşhane, kütüphane, marangozhane, eczane, hastane gibi birçok yapılar meydana getirilmişti (Çiçek, 2000, s. 69). 1904'de Merzifon Amerikan Koleji'nde, gizli olarak Rumlar tarafından "Rum İfanperver Cemiyeti" ve "Orpheus" adında bir musiki kulübü. Bu cemiyetler daha sonra birleşerek ilk "Pontus Cemiyeti" ni teşkil etmişlerdir (Tansel, 1985, s. 91). Pontus Cemiyeti 1910'da "Pontus" adlı bir broşür yayınlamıştır.

1921'de Kolej'in aranması sırasında, bu cemiyete ait evraklardan olarak, 1919 - 1920 yıllarına mahsus zabıtname parçaları ele geçirilmişti. Bunlar Türk düşmanlığını sürekli ve şiddetle telkin eden tutanaklardı. Yine bu zabıtlardan anlaşıldığına göre, Pontus tarihi ve askeri konularla ilgili konferanslar verilmiş, Rum asker kaçaklarına ve bölgede Rum nüfusunu arttırmak amacıyla bölgeye getirilen göçmenlere yardım edilmişti. Patrikhane'nin de bu cemiyete üç bin lira gönderdiği, yine bu belgelerden anlaşılmaktaydı (Arşiv Belgeleriyle Rum Faaliyetleri, ss. 288 - 292). Mustafa Kemal Paşa'nın Havza'dan Harbiye Nezareti'ne çektiği telgraftan anlaşıldığına göre, Kolej'e içinde silah 
olması muhtemel sandıklar gelmekte, Merzifon'daki İngiliz subayları Kolej'de toplantılar yapmakta ve komitacılıkla uğraşmaktaydılar (Arşiv Belgeleriyle Rum Faaliyetleri, s. 26).

Merzifon Amerikan Koleji'nin bölgedeki faaliyetleriyle bir okul olmaktan çok, siyasi bir kulüp olduğu ortaya çıkmıştı (Arşiv Belgeleriyle Rum Faaliyetleri, s. 284). Rum çetelerinin gittikçe artan tecavüzleri ve bunun yarattığı asayişsizlik, içte büyük bir anarşi unsuru olmaya başlamıştı. Bu arada Kolej'in Türkçe öğretmeni Mehmet Zeki Bey 14 Şubat 1921'de bir silahlı saldırı ile öldürülmüştür. Kolej'e yapılan baskın sonrasında yapılan soruşturma neticesinde Mehmet Zeki Bey'in Merzifon Amerikan Koleji'nin yönetim kurulu kararıyla, Kolej'deki bölücü faaliyetlerin ihbar edileceği endişesi sonucu şehit edildiği anlaşılmıştır (Gedikli, 2002, ss. 423 - 424; TBMM Zabıt Ceridesi, Cilt 15, s. 241). Öğretmen Mehmet Zeki Bey'in şehit edilmesi ve evvelce kolej hastanesinde çalışmış bir Müslüman kadının Kolej içinde gizli yollar, depolar bulunduğu, buralarda silah ve cephane gizlendiği, gizli toplantılar yapıldığı, Hastane çalışanlarının dağlarda faaliyet gösteren Rum çeteleriyle temasta bulunduğu yolundaki ihbarı üzerine, Kolej'in, 16 Şubat 1921'de aranmasına karar verilmiştir (Arşiv Belgeleriyle Rum Faaliyetleri, s. 267).

Yapılan arama neticesinde elde edilen bulgular ve Kolej aleyhindeki deliller Bakanlar Kurulu'nun kararı ile İstanbul'da bulunan ABD temsilcisi Amiral Bristol'e bir nota ile bildirilmiştir. Buna göre 16 Şubat 1921 tarihinde 5. Tümen Komutanı'nın gözetiminde Kolej'de yapılan aramalarda, adı geçen okulu yönetenlerin Türkiye aleyhinde faaliyette bulundukları ortaya çıkmıştır (HTVD, S.72, Vesika: 1579). Ayrıca notada, Kolej dâhilinde olan Pontus'çuluk faaliyetlerinden bahsedilerek, “Pontus Cemiyeti”ne ait bayrak, mühür, armalar bulunduğu, Türkçe Öğretmeni Zeki Bey'in bu faaliyetlerin bir sonucu olarak katledildiği, tarafsız olması gereken bir eğitim kurumunun Türklerin samimiyetini suiistimal ederek zararlı faaliyetlerde bulunmuş olduğu belirtilmiştir (Balcıoğlu, 2000, s. 95). Kolejin aranması sırasında ele geçen belgelerden, Rum ve Ermeni gençlerin Avrupa'ya kaçırılması hususunda Kolej bünyesinde çalışmaların olduğu anlaşıımıştı. Kolej Müdürü’ne ait bir belgede de, Hıristiyanlığın en büyük rakibinin İslâmiyet, en güçlü İslâm Devleti'nin de Türkiye olması sebebiyle, buradaki çalışmalarının 500 sene sürse dahi başarıya ulaşması gerektiği yazılmıştı. Böylece, Kolej bünyesinde bulunan, devlet ve hükümet için zararlı faaliyetleri tamamen ortaya çıkan Pontus Cemiyeti'nin yönetim kurulu üyesi altı kişi ve Kolej talebelerinden olan, Öğretmen Zeki Bey'in katilleri tevkif edilmişlerdi. Bir taraftan eğitim öğretime ara verilip sınıflar mühürlenirken Dâhiliye Vekaleti'nin emriyle de, okulun muhafazası ve yetimhanede bulunan 290 Ermeni ve Rum çocuğun bakımı için biri karı koca, biri bekar olmak üzere üç Amerikan vatandaşı alıkonularak, diğer 29 Amerikalı Samsun yolu ile ülkeden çıkarılmışlardır (Yazıcı, 1989).

\section{Milli Mücadele Döneminde Pontus Sorunu}

\subsection{Milli Mücadele Öncesi Pontus Sorunu}

Pontus Sorunu Osmanlı yönetiminin baskı ve şiddetinden değil, dış kaynaklı faktörlerden kaynaklanmıştı (Pontus Meselesi, s. 15). Pontus Rum Devleti'nin kurulması Megalo İdea'da ifadesini bulan Yunan emperyalizminin hedefleri arasındaydı. Türklerin bir iç gaileyle veya dış tehditle uğraştıkları sırada harekete geçmeyi geleneksel bir politika haline getirmiş olan Yunanistan'ın bu konu- 
Mustafa Yahya METiNTAŞ | Mehmet KAYIRAN

daki önemli bir destekçisi Türklerin mabetlere olan saygısını istismar edip her türlü yıkıc faaliyeti gösteren İstanbul'daki Patrikhane idi. Dışarıda Yunanistan, içeride Patrikhane Osmanlı Devleti'nde Rumluk akımını güçlendirmeye çalışan iki etkili merkezdi. Bu konuda Yunanistan'ın ve Patrikhane'nin destekçileri, emperyalizmin ülkemizdeki ajanları olan ve kapitülasyonlardan yararlanarak serbestçe faaliyet gösteren yabancı okullar ve misyonerlik kuruluşlarıydı (Türk İstiklal Harbi, ss. 282 - 283). Başta Yunanistan ve Patrikhane olmak üzere bunların görevi Türkiye'de yaşayan Rumları ayaklandırmak ve ülkede karışıklıklar çıkararak Avrupa'nın müdahalesini sağlamaktı (Arşiv Belgeleriyle Rum Faaliyetleri, s. 31). Böyle bir müdahalede doğuda yeni siyasi ve iktisadi çıkarlar peşinde koşan Avrupa devletlerinin siyasetlerine uygun düşmekteydi (Pontus Meselesi, s. 28).

Pontus Sorunu Mondros Mütarekesi'nden sonra da yine aynı güçler tarafından, aynı yöntemlerle ortaya atılmış; sömürgeci devletlerin çıkarlarına hizmet ettiği sürece canlı tutulmaya çalışılmıştı. Karadeniz Bölgesi zengin hinterlandı, dikkate değer sayıdaki Rum nüfusu ile Birinci Dünya Savaşı'ndan sonra'da Yunan deniz ticaretinin aradığı ve faydalandığı bir bölgeydi. Yunan emperyalizminin Osmanlı Devleti'nin bu en zayıf devrinde hayallerini canlandıran ümit daha çok böyle bir iktisadi sebebe dayanmaktaydı (Türk İstiklal Harbi, s. 282). Pontus Sorununu hiç yoktan var ettiğini iddia eden Yunan Başbakanı Venizelos, Birinci Dünya Savaşı'ndan sonra toplanan Paris Barış Konferansında Pontus Sorununu benimsememiş gibi görünse de daha sonra Venizelos'un savaş hedefleri arasında Anadolu'nun kuzeyinde bir Pontus Devleti'nin kurulması da yer almıştı (Jaeschke, 1971, s. 90; Nutuk, Cilt 2, s. 627). O’na göre, böyle bir devlet özellikle Rus emperyalizmine ve Müslüman yayılmacılığına karşı bir set vazifesi görebilecekti. Yunanistan'ı bu konuda cesaretlendiren asıl faktör ise Müttefikleri'nin teşvik edici ve destekleyici tutumları idi. İtilaf Devletleri'nin Mondros Mütarekesine koydukları özellikle 24. maddeden amaçları Pontus ve Ermeni komitelerini harekete geçirip kargaşalıklar çıkartarak Doğu Anadolu'da bir Ermenistan sahilde de bir Pontus Rum Devleti kurmaktı (Aralov, 2008, s. 36). İngilizler İstanbul Boğazı'nın Anadolu yakasının yukarı kısmını Yunanılıara işgal ettirirken Karadeniz'de kurulacak bir Pontus Devleti'ni de dikkate almışlardı. Mütareke'nin Yunanistan'a sağladığı çok önemli bir üstünlük de Osmanlı donanmasının etkisiz bırakılmış olmasıydı. Yunanistan ve Müttefikleri böylece Karadeniz kıyılarına serbestçe gidip bölge Rumlarını kışkırtma, onlara her türlü yardımı yapabilme imkânı bulmuşlardı (Arşiv Belgeleriyle Rum Faaliyetleri, s. 41). İtilaf Devletleri, Karadeniz bölgesinde başlatılacak bir Rum ayaklanması ile Türk ordusunu iki taraftan kuşatıp yok etmeyi amaçlamıştı (Pontus Meselesi, s. 7).

Birinci Dünya Savaşı sırasında Rus Bolşevik ihtilali sonrasında sinmiş görünen Karadeniz Rumları her an tetikte bekliyor, harekete geçmek için firsat kolluyordu. Nitekim mütarekeyi ve uygulamalarını fırsat bilen Rumlar bu defa Batı'dan gelen düşmanlarla işbirliğine girmişlerdi. ABD Başkanı Wilson'un yayınladığı ilkeleri kendilerine göre yorumlayarak Pontus Rum Devleti'ni kurmak amacıyla harekete geçmişler ve Avrupa'ya heyetler göndermişlerdi. Sadece siyasi faaliyetlerle de yetinmemişler işi fiili ayaklanmaya kadar götürmüşlerdi. Buna cesaret edebilmelerinin başlıca sebebi Birinci Dünya Savaşı yıllarında Ruslar tarafından büyük ölçüde teşkilâtlandııımış ve silahlandırımış olmalarıydı. Bu faaliyetler mütarekeden sonra yeniden hız kazanmış, gerekli para ve silah Patrikha- 
ne ve bağlı kuruluşlarıyla Yunanistan ve İtilaf devletlerince sağlanmıştı. İçinde tümenler donatacak kadar silah ve levazım bulunan Fener Patrikhanesi ve bağı kuruluşlarında her ayinde mukaddes ideal adına açık ve gizli para toplanmakta, zenginlerin yaptıkları yardımlar buna eklenmekteydi. Atina'daki Etnik-i Eterya'nın şubeleri olan Küçük Asya ve Pontus Cemiyetleri'nin aracılık ettiği silahlanma faaliyetlerinde taşıma işlerini kapitülasyonlardan yararlanan Yunan tüccarlarının gemileri yapmaktaydı. Bütün bu faaliyetlerin destekçisi olan Yunanistan Devleti, bütçesinden Pontus'çu faaliyetleri desteklemek için belli bir pay bile ayırmışı (TBMM Zabıt Ceridesi, c. XV, s. 239). Ayrıca, mütareke sonrasında İtilaf ve Yunan donanmalarının sık sık Karadeniz kıyılarında görünmeleri ve teftiş bahanesiyle karaya çıkan İtilaf subaylarının Rumları kışkırtmaları, Türklerin silahlarının alınmasına karşılık Rumların yoğun şekilde silahlandııımaları (Özel, 1991, s. 37), nihayet Rusya'dan göçmen adı altında getirilen Rumlarla Rum nüfusun arttıııması çabaları Pontus Ayaklanması'nı teşvik eden diğer hususlar olmuştu (ATASE, ISH, K: 314, G: 129; ATASE, ISH, K: 89, G: 327). Mütareke döneminde Karadeniz Bölgesine Rusya ve Kafkasya'dan Rum göçü devam etmiştir. Mondros Mütarekesi'nin imzalanmasından sonraki ilk altı ay içinde sadece Trabzon'a çoğu silahlı 8.000'i aşkın Rum gelmişti. Giresun'a ise Eylül 1919'a kadar gelen Rum göçmen sayısı 525 kişi idi (ATASE, ISH, K: 88, G: 322).

Mütarekeden sonra Pontus Sorunu Paris Barış Konferansı'nın gündemine sokulduğundan bu meseleyle ilgili siyasi faaliyetlerin ağırlık merkezi Avrupa'ya kaymıştı. Yunan emperyalizmini sistemli olarak yansıtan Yunan basını sadece İzmir için değil, İstanbul ve hatta Türkiye'nin topraklarında bir Pontus Cumhuriyeti kurulması tasarlanan bölgesi Karadeniz için de yaygara koparmaktaydı (Sonyel, 1973, s. 31). Avrupa'da öteden beri Pontus konusundaki siyasi faaliyetleri ile dikkat çeken ünlü Anadolulu Rum tüccar Konstantin Kostantinides'in Marsilya'daki Pontus Komitesi adına İngiliz gazetelerine gönderdiği bir mektupta: Karadeniz sahillerinde merkezi Samsun olmak üzere Kafkasya'dan Sinop'a kadar uzanan bölgede çok miktarda Rum unsurunun sakin bulunduğu, içerilere doğru 140 - 160 mil genişliğindeki bu arazinin Bizans'lı Komnenos'un kurduğu Rum Imparatorluğu'na dâhil olduğu, buralarda Türk yönetiminin kesintisiz baskılarına maruz kalan bir milyon'a yakın Rum'un yaşadığını ileri sürmüş; bu Rumların bugün Paris Barış Konferansı'nın gelecekleri hakkında vereceği kararı sabırsızlıkla bekledikleri ve Karadeniz Rumlarının meşru arzu ve isteklerinin Karadeniz Cumhuriyeti adında bağımsız bir Rum hükümetinin kurulmasından ibaret olduğunu ifade etmiştir (Pontus Meselesi, ss. 28 - 31). Avrupa'da Paris Barış Konferansı arifesindeki bu siyasi faaliyetlere paralel olarak Karadeniz Rumları da Samsun merkezli bir Pontus Rum Devleti'nin kurulması için Avrupa merkezlerini ziyaret etmek üzere komiteler teşkil etmişlerdi (Jaeschke, 1971, s. 57).

Pontusçular bütün gayretlerine rağmen Paris Barış Konferansı'nı istedikleri doğrultuda yönlendiremediler. Buna rağmen Pontusçuluk çalışmaları zayıflamadı hatta hız kazandı. Örneğin Trabzon Metropoliti Hrisantos, Oflu ve Tonyalıların bile Rum olduklarını iddia ediyordu (Turan, 1999, s. 31).

Karadeniz bölgesinde yaşayan Rumlar, 23 Şubat 1919'da “Rum Karadeniz Cumhuriyeti” adıyla yeni bir devlet kurma kararını almışlardı. Bunu gerçekleştirebilmek için de kararlarını İngiliz Yüksek Komiserliği'nin onayına sunmuşlardı. Bu kararı alan kişiler, Amasya ve Samsun bölgesi rum Metro- 
Mustafa Yahya METiNTAŞ | Mehmet KAYIRAN

polidi Yermanos, Samsun'daki Reji fabrikası müdürü Tokomanidis ve Trabzon Rum Metropolidi Hrisantos'tu (Genelkurmay Başkanlığı, TSK Tarihi, C. IV, s. 518 - 519). Bunlar ayrıca İstanbul'da Pontus adlı Rumca bir gazetenin de yayınına başlamışlardı. Gazete 4 Mart 1919'da çıkan ilk sayısında, Trabzon'da bir Rum Cumhuriyeti kurulmasına çalışacağını açıklamıştı (Turan, 1991, s. 112).

Doğu Karadeniz bölgesinde Rumlar tarafından Pontus Devleti'nin kurulması için başlatılmış olan ayaklanma Yunanlıların, İstanbul'daki Rum Patrikhanesi'nin, Amerika'nın maddi ve manevi yardımına güvenerek genişleme eğilimi göstermekteydi. Rusya ve Kafkasya'daki Rumların, Trabzon çevresindeki bölgeye göç ettirileceği söylentileri Pontus Sorununun önemini 1919 yılı başından itibaren bir kat daha arttırıyordu (Türk İstiklal Harbi, C. VIII, s. 28).

Mütareke döneminde daha önce Rusların organize ettiği Pontus çeteciliğini örgütleme ve faaliyete koyma görevini Yunanistan üstlenmişti. Bu iş için görevlendirilen subay heyetleri yöreye Kızılhaç heyetleri ile gönderilmekteydi (Nutuk, s. 627). Yine bu amaçla İstanbul'da Galata'da Minerva Hanı'nda "Rum Muhacirleri Merkez Komisyonu" açık adıyla faaliyet gösteren, gerçekte Etnik-i Eterya'nın şubesi olarak "Kordos" gizli adını taşıyan bir komite kurulmuştu. Sandragos takma adını kullanan Yunanlı Manul Jozukas'ın başkanlığında faaliyet gösteren cemiyet Yunan Hükümeti'nin maddi ve manevi yardımını görmekteydi (Gökbilgin, 1959, ss. 154 - 155). Anadolu'da silah ve cephanenin teslim edildiği yerler olan Samsun ve Trabzon'a gelen Rum göçmenleri arasında Yunan subayları ve eğitimli askerler de bulunmaktaydı. (Arşiv Belgeleriyle Rum Faaliyetleri, s. 58) Bunlar arasında sakal bırakıp papaz kıyafetine girenler ve kadın gönüllüler de bulunuyordu (Yılmaz, 2010, s. 97).

Yunanistan tarafından Batum'da "Pontus Cumhuriyeti" adıyla Yunan görevlilerinden oluşan bir idare heyeti kurulmuştur. Bu yapının görevi Trabzon ve çevresinde asayişi bozarak yabancı devletlerin müdahalesi sayesinde bir işgal sahası oluşturmaktı. Nitekim Trabzon'da Pontus'çu mücadeleye katılmak üzere üzere Batum'da teçhiz edilen Haçık adlı bir Rum'un idaresindeki 17 kişilik bir çete, 12/13 Temmuz 1919 gecesi Giresun yakınlarında motorla karaya çıkınca, gruba müdahale eden askeri birlik liderleri dâhil 10'unu ölü diğerlerini ise yaralı olarak ele geçirmiştir (ATASE, íSH, KLS: 183, G: 85). Özellikle Trabzon Rum Metropoliti Hrisantos bu organizasyon içinde önemli roller üslenmiştir (Arşiv Belgeleriyle Rum Faaliyetleri, s. 156).

Öte yandan İngiliz ve Fransızlar Trabzon, Samsun ve Sinop kıyısındaki Rumları kışkırtıyor, Amerikalılar da Pontusçu faaliyetlere alet oluyorlardı. Nitekim Mondros Mütarekesi'ni takiben bir FranSIz, üç İngiliz savaş gemisinden oluşan İtilaf Devletleri Filosu'nun Karadeniz kıyılarına yaptığı gezi Pontus'çuları cesaretlendirmiş tedhiş̧̧ilerin faaliyetlerini arttırmalarına yol açmıştı (Tansel, 1991, s. 99). Yine 9 Mart 1919'da 200 kişilik bir İngiliz müfrezesinin Samsun'u, 30 Mart'ta Merzifon'u işgal etmesi Samsun ve dolaylarında bir Pontus Hükümeti'nin kurulmasını teşvik amacı taşımıştı (Türk İstiklal Harbi, s. 32). Samsun ve yöresindeki İngiliz işgali Pontus'çuları iyiden iyiye cesaretlendirmiş, Alexander İhtiyaroğlu adındaki bir Rum hükümet konağına gelerek: “Alçak, namussuz Türkler, 
gidiniz. Burası Rum hükümetidir. Hükümet teşkil ettim. Bu belediye dairesi de Pontus Hükümeti'nindir" demişti (TBMM Gizli Celse Zabıtları, Cilt 2, 1985, s. 441).

Giresun Rumları 8 Mayıs 1919 sabahı sözde doktor ve ilaç getiren, gerçekte silah ve komiteci getirdiğinden şüphe edilmeyen Yunan kızılhaçının gemisini Yunan bayrakları ve orkestra ile karşılamışlardı. Karşılayıcılar arasında Osmanlı Devleti'ne bağlıı̆ı̆ından dolayı padişahtan nişan alan Payanotoğlu Murat ile Giresun Metropoliti Lavrandiyos Efendi de bulunmuş ve Pontus bayrağı altında resim çektirmişlerdi. Ayrıca mütareke sonrasında Rum okullarına Pazar günleri Yunan bayrağı çekmeye başlayan Rumlar 11 Mayıs 1919 Pazar gününden sonra şehir merkezindeki Rum okulunda Yunan bayrağını asılı tutmakta inat etmişlerdi ( Çapa, 1993, s. 75).

Yayınlanan Rum gazetelerinde Pontus'çuluk propagandası yapılıyor, Pontusçular Yunanlıık iddialarını pervasızca açıklıyorlardı. Nitekim mütarekeden sonra Trabzon'daki bir dava sırasında dava vekili Akriditi'nin: “Şimdiden sonra Türklerin buralarda hakkı hayatı yoktur. Buraları Pontus Hükümetine aittir" sözleri mahkeme kayıtlarına geçmişti (TBMM Gizli Celse Zabıtları, Cilt 3, ss: 363-368). Rumlar Yunanistan'ın bağımsızık günü olan 7 Nisan 1919'da coşkun gösteriler yapmışlar, okullarına Pontus bayrağı çekmişlerdi (Goloğlu, 1973, s. 240).

İtilaf Devletleri Donanması'nın Pontus'çulara cesaret veren faaliyetlerine 1919 illkbaharında Yunan torpidolarının ziyaretleri eklenmişti. Bu ziyaretler sırasında Yunan subayları için karşılama törenleri yapılıyor, şenlikler ve gösteriler düzenleniyordu. 27 Nisan 1919'da Trabzon’a bir Yunan savaş gemisi gelmiş, gece vakti sarhoş durumdaki birkaç Yunan askerinin bir erin silahını almaya kalkışması üzerine Türk eri bunlardan birini öldürmüştü. İtilaf memurları bu gelişme üzerine valiye ve o sırada Erzurum'a gitmek üzere Trabzon'da bulunan XV. Kolordu Komutanı Kazım Karabekir Paşa'ya başvurmuşlar, Türk erinin cezalandııımasını ve Yunan eri için tören yapılmasını istemişlerdi. İtilaf görevlilerinin bu isteği kabul edilmemiş, Türk erinin bu hareketi bir nefis ve namus müdafaası sayıldığından kendisine ceza verilmemiştir (Karabekir, s. 21).

Yunan ordusunun İzmir'i işgalinin yaklaştığı günlerde İstanbul'da Patrik Vekili Dreteos'un başkanlığında kurulan ve doğrudan Venizelos'tan emir alan Mavri Mira Derneği Pontus projesini gerçekleştirmek üzere gerekli hazırlıkların tamamlandığı düşüncesi ile harekete geçmişti. Dernek Venizelos'a Türklerin hiçbir karşı harekete geçemeyeceği inancı ile diğer unsurlardan önce eyleme geçmek ve Karadeniz kıyılarında bağımsız bir Rum Devleti kurmak için derhal faaliyete geçmek kararında olduğunu, bunun için bütün tedbirlerin alındığını, silahlı ve teçhizatlı milis birliklerinin mücadeleye başlamak için sadece Yunan subaylarını beklediklerini bildirmişti.

Mütareke döneminde, Yunanistan'ın büyük bir çıkarma yaparak Karadeniz Bölgesine müdahale edeceği söylentisi bölgede çetecilik faaliyetlerinin artmasına yol açmıştır. Bu söylentiye göre Yunanistan'da 30.000 kişilik bir ordu teçhiz edilmişti ve bu ordunun tek görevi Trabzon ve çevresine bir çıkarma ile müdahale etmek ve bölgede kurulması planlanan Rum devletini güvenlik altına almak olacaktı (ATASE, ISH, Kls: 368, G: 38).

Mütareke döneminde Pontus projesinin dayandığı temel unsurlardan biri de Trabzon ve yöresine Kafkasya'dan, Rusya'nın Karadeniz sahillerinden ve Osmanlı Devleti'nin diğer yörelerinden 
Mustafa Yahya METiNTAŞ | Mehmet KAYIRAN

Rum göçmenler getirerek iskân etmek, böylece bölgede nüfus üstünlüğünü sağlamaktı (Arşiv Belgeleriyle Rum Faaliyetleri, ss. 138 - 185). Bu husus, Rumların bölge üzerindeki iddialarına ciddiyet kazandırabilmelerinin bir yolu olarak görünmüştü (Özel, 1991, s. 45). Trabzon Metropoliti Hrisantos'a göre, Güney Rusya Kafkaslar'daki Rumlar Karadeniz'in sahillerine taşınmaya başlamıştı. 19 Mayıs 1919 sonlarına kadar 250.000 Rum bölgeye taşınmıştı. Bu yeni göçmenlerden yararlanarak silahlı çeteler oluşturulmuştur (Turan, 1991, s. 112).

Pontusçu Rumların bölücü faaliyetleri hızla sürerken 10 Aralık 1918'de bölgedeki mücadelenin ilk somut adımı olan İstikbal Gazetesi Trabzon'da yayınlanmaya başlamıştır. Barutçuzade Faik Ahmet ve Mehmet Salih (Ongan) gazetenin kurucularıdır (Özel, s. 53). Bu kişiler kısa süre sonra bölgedeki Kuvayı Milliye örgütlenmesi içinde de aktif rol alacaklardır. Trabzon'da yayımlanan İrşad, Samsun'da Ahali, Hayat, Aksiseda, Giresun'da Işık, Ordu'da Güneş ve Kastamonu'da Açıksöz gazeteleri yayımlanmaya başlamıştır (Doğanay, 2001, s. 259). Ancak bu gazetelerin yayın faaliyetleri itilaf Devletleri tarafından sürekli sansüre uğramış ve engellenmiştir. Bölgedeki milli örgütlenmenin liderleri, o dönemde önemli bir mücadelenin sürdürüldüğü Elviye-i Selase'de (Kars, Ardahan ve Batum) yapılacak kongrelere katılma kararı almışlardır. Bu doğrultuda 7 - 9 Ocak 1919'da yapılan Ardahan Kongresi'nde "bölgedeki yayın organlarının milli mücadele yolunda iç kuvvetleri bilgilendirerek uyarması ve dışarıya karşı da milli hakları tanıtması" kararı alınmıştır. 17-18 Ocak tarihli Kars Kongresi'nde ise Trabzon teşkilatının oluşturulması ve teşkilatın başına alay komutanı Ali Rıza Bey ve Barutçuzade Hacı Ahmet Efendi'nin getirilmesi kararlaştırılmıştır. Giresun Teşkilatı'nın da kurulması ve bu amaçla Topal Osman Ağa ile konuşulması kararlaştırımıştır (Yılmaz, 2010, s. 136). Bu kararlardan sonra 10 Şubat 1919'da Trabzon Muhafaza-i Hukuku Milliye Cemiyeti kurulmuştur. Milli Mücadele'nin en etkili örgütlenmelerinden biri olan Trabzon Cemiyeti Erzurum Kongresi'nin toplanmasına da büyük katkı sağlamıştır.

Mustafa Kemal Paşa'nın Samsun'a çıkışına kadar bölgenin asayişi İstanbul Hükümeti ve yerel oluşumlar tarafından sağlanmaktaydı. Harbiye Nezareti 3 Nisan 1919 tarihinde bölgedeki askeri birliklerle ilgili yeni bir düzenleme gerçekleştirmiştir. Bölgede bulunan 9. Ordu lağvedilmiş Trabzon bölgesi Kazım Karabekir Paşa'nın komutan olarak atandığı 15. Kolordu'nun sorumluluk alanına dâhil edilmiştir. Pontus çeteleri ile mücadele görevi ise özel olarak oluşturulan takip alaylarına bırakılmıştır. İlk olarak 182, 582 ve 45 numaralı üç takip alayı oluşturulmuş ancak 1919'da bu üç alay 45. Takip Alayı altında birleştirilmiştir. 45. Takip Alayı'nın görev alanı Samsun olacaktır. Yine Sivas'ta merkezlenen Refet Paşa komutasındaki 3. Kolordu, Cemil Cahit Bey komutasındaki 5. Kafkas tümeni bölgede görev yapan diğer askeri birliklerdir. Mütarekeden sonra askeri birliklerin personel, silah ve cephanelerine getirilen kısıtlamalar nedeni ile Rum çetelerine karşı yürütülen mücadele çok zor şartlar altında sürdürülür hale gelmiştir (İstiklal Harbinde Ayaklanmalar, 1974, ss. 289310). 


\subsection{Milli Mücadelede Pontus Sorunu}

1920 yılı başında Yunan harekâtına paralel olarak Rum çetelerinin faaliyeti yeniden yükselişe geçmiştir. 1920 sonlarına doğru Karadeniz kıyılarında, Samsun, Çarşamba, Bafra, Erbaa, Zile'deki Rum köylerinde, Rumlar geniş çete faaliyetlerine giriştiler. Başlangıçta 6-7 bin silahlı kadar tahmin edilen Pontus'çular, daha sonra 25 bin kadar silahlı kuvvete ulaştılar. Bu durumda Kurtuluş Savaşı'nın en çetin günlerinde Ankara Hükümeti, askeri önlemler almak zorunda kaldı. 1920 sonu ve 1921 başlarında III. Ve XV. Kolordular, bu bölgelere önemli askeri birlikler gönderdiler. Daha sonra III. Kolordu, Birinci Merkez Ordusu şeklinde yeniden organize edildi ve Pontus Sorunu'nun halli bu orduya bırakıldı (Nutuk, Cilt 2, ss. 629 - 630). 1921 yılı boyunca yoğun bir faaliyet yaşandı. Bu hareketlerde Pontus'çulara ait 117 büyük sığınak tahrip edildi. Resmi makamlara göre 3,877 Pontusçu öldürüldü. Bu arada Pontusçular da, 439 Türk köyünü yaktılar, asker ve halktan önemli kayıplara sebep oldular (Türk İstiklal Harbi, Cilt 4, ss. 290 - 293). Merkez Ordusu'nun gücü 1921 sonlarında 20.000'e çıkarıldı. Alınan diğer idari önlemlerin yanısıra özellikle bu ordunun emekleri ile Pontus Ayaklanması 1923 yılında sona erdirilmiştir (Genelkurmay Başkanlığı, 1984, s. 518 - 519). 1921 sonunda ve 1922 başında Karadeniz Bölgesi'ndeki Rum nüfusun Yunanistan'a taşınması başladı. Bu durum Karadeniz Bölgesi'ndeki Rum nüfusun ortadan kalkmasına ve Türkiye'de ulusal birliğin sağlanması yönünde önemli bir etken oldu.

Mustafa Kemal Paşa 15 Temmuz 1920'de 3. Kolordu, 5. Fırka, 15. Fırka ve Samsun MutasarrıfIığına gönderdiği bir şifreyle, Yunanlıların bir çıkarma yapması ihtimaline karşılık "1. Askeri kıtaların mevcutlarının arttırımasını ve lüzumlu görülen tüm askeri tedbirlerin alınması 2. İngilizlerin ani baskınlarla esir alma girişimlerine karşı tüm askeri ve sivil erkânın uyanık ve tedbirli olması, 3. Rumların çıkarma yapacak kuvvetlere yardım etmeleri ihtimali nedeniyle askeri ve mülki kati tedbirlerin düşünülmesi" konularında uyarılarda bulunmuştur (Askeri Tarih Belgeleri Dergisi, 9. Cilt, ss. 57 58).

Karadeniz Bölgesinde Pontusçu çetelere karşı yürütülen mücadelenin en önemli isimlerinden biri de Giresunlu Topal Osman Ağa'dır. Giresun Milli Mücadele teşkilatının kurucusu olan Topal Osman Ağa burada yürüttüğü etkili mücadele ile kısa sürede Rum çete faaliyetlerini sona erdirmiştir. Giresun'un ardından Samsun'da da Topal Osman Ağa ve ona bağı olan 42. Piyade alayından istifade edilmiştir. Topal Osman Ağa ve 42. Piyade Alayı, 16 Nisan 1921'de Samsun'a gelmiş ve mücadeleye başlamıştır. Kısa süre içinde önce Samsun Kaza merkezinde ardında da Samsun kırsaIında Rum çetelerinin faaliyetleri engellenmiştir. Topal Osman Ağa'nın Rum çetelerine karşı mücadelede gösterdiği başarı yabancılar arasında yankı bulmakta gecikmedi. Samsun Amerikan Konsolosu İstanbul'a gelip Topal Osman Ağa'nın faaliyetleri hakkında İngiliz Yüksek Komiserliğini haberdar etmişti (ATASE, ISH, K: 633, G: 35).

\section{Merkez Ordusu ve Faaliyetleri}

\subsection{Merkez Ordusu'nun Kuruluşu ve Konuşlanışı}

TBMM Hükümeti, 9 Aralık 1920 tarihinde “Anadolu merkezindeki asayiş meselesini halle memur kuvvetlerin büyük bir kumanda altında birleştirilmesi" kararı çerçevesinde 3 Kolordu'nun 
Mustafa Yahya METiNTAŞ | Mehmet KAYIRAN

kaldırılmasına onun yerine de karargahı Amasya'da bulunacak ve Pontus isyanı başta olmak üzere isyanların bastırıması için mücadele edecek Merkez Ordusu'nun kurulması çalışmasını başlattı. Lağvedilen 3. Kolordu'ya bağlı 5. Kafkas Tümeni, 15. Tümen, 6. Piyade Tümeni ve 13. Bağımsız Süvari Tugayı yeni kurulan Merkez Ordusuna bağlanmıştır. Merkez Ordusu Komutanlığı'na Nurettin Paşa getirilmiştir (Yılmaz, 2010, s. 143).

Mütareke dönemi boyunca Yunanistan ve İtilaf Devletleri tarafından Karadeniz bölgesinde Rumların yaşadığı bölgeler adeta silah deposu haline getirilmişti. Bölgede asayişin temini için görevlendirilen Merkez Ordusu Rumların elinde bulunan silahların toplanması kararını almış ve Rumlara çağrı yaparak belirli, günlerde silahların hükümete teslimini istemiştir. Bir kısım Rumlar bu çağrıya uyduysa da uymayanlar çoğunlukta olmuş daha sonra yapılan aramalarda 2.000'den fazla silah ve 1 milyon 200 bin fişek toplanmıştır (Pontus Meselesi, s. 387).

16 Şubat 1921'de Merkez Ordusu Merzifon Amerikan Kolejine bir baskın düzenlemiş, baskın sonucunda ülkedeki Pontus örgütlenmesi ile ilgili pek çok belge ele geçirilmiştir. Bu baskın sayesinde, Fatsa, Ünye, Kırşehir, Kavak, İnebolu, Havza, Çarşamba, Bafra, Sinop, Kayseri, Ürgüp ve Tokat bölgelerine kadar örgütlenmesini genişletmiş olan Müdafaa-i Meşrute Komitesi; "Yunanistan'ın çağrısına kulak asmayan ve itaat etmeyenlerin cezalandırılacağının" yazılı olduğu bir yönetmeliği olan Samsun Mukaddes Anadolu Rum Cemiyeti ve merkezi Trabzon'da bulunan Pontus Muavenet Heyeti ortaya çıkarılmıştır (Yılmaz, 2010, s. 149).

\subsection{Merkez Ordusu'nun Faaliyetlleri}

Milli Mücadelenin başlarında Rum nüfusu genel nüfusun yüzde onu kadardı. Yörede 250.000 Hıristiyan, 2.350.000 Türk ve Müslüman yaşıyordu. Trabzon vilayetinde 20.000 Hristiyan'a karşılık, 317.000 Müslüman; Giresun Sancağında ise, 10.000 Hıristiyan'a mukabil 190.000 Müslüman vardı (Çapa, 1993, s. 12).

Milli Mücadele sırasında Karadeniz bölgesinde yaşayan ve sürekli bir istikrarsızlık kaynağı durumunda olan Rumların savaştan uzak iç bölgelere nakli önemli bir tartışma konusu olmuştur. Yunan donanmasının 9 Haziran 1921 tarihinde İnebolu sahillerini bombalaması Yunan ordusunun Karadeniz bölgesine bir çıkarma yapacağı endişesini doğurmuştur (ATASE, ISH, K: 635, G: 205). Savaşın en şiddetli günlerine rastlayan Yunan bombardımanı Rum nüfusun Karadeniz bölgesinden uzaklaştırıması tartışmasını canlandırmış, Bölgede Rum çeteleri ile mücadele halinde olan Merkez Ordusu'nun teklifi üzerine TBMM, 16 Haziran 1921 tarihinde konuyla ilgili bir kararname çıkarmıştır. Bu kararname ile "Karadeniz sahilinde eli silah tutan 15 - 50 yaşındaki Rumların dâhile sevk edilmesi” kararı alınmıştır (ATASE, ISH, K: 1112, G: 86). Dâhiliye Vekili Fethi Bey, Meclis'in 29 Aralık günlü toplantısında tehcir kararının alınmasını şöyle açıklamaktadır: "Yunan ordusunun ileri harekâtı başladı. Bunun üzerine Pontus'çularla alakadar olanlar ve bu Pontus teşkilatının aleti olan çeteler bir umumi ayaklanma ile memleketi büsbütün parçalama zamanının geldiği fikrine kapıldılar ve birçok tezahüratla umumi ayaklanmaya başladılar. Bunun için hükümetçe düşünülen tedbir, oradaki Rumları toplamak ve 18 yaşından 50 yaşına kadar olan Rumları ahar mahalle sevk eyleye- 
rek askerimizin arkasındaki tehditkâr vaziyetlerine nihayet vermekti" (TBMM Zabıt Ceridesi, Cilt 15, 1958, s. 240; Yılmaz, (2010), s. 150).

Stefanos Yerasimos'a göre, ilk sevkiyatlar 16 ve 17 Haziran'da yapılmış bu kafileler sevkiyat esnasında uğradığı saldırılar neticesinde 300 - 700 arasında kayıp vermiştir. 1,000 kişilik üçüncü kafile 20 Haziran'da yola çıkmıştır. Dördüncü kafile 25 Haziran'da yola çıkmıştır. 17, 21, 24 Haziran tarihlerinde Bafra'dan yola çıkan 3 kafilenin her birinde 500 - 600 kadar Rum bulunmaktadır. Yerasimos, Yunan kaynaklarına dayanarak Eylül ayından itibaren yaşlı, kadın ve çocukların da iç bölgelere sürüldüğünü belirtmektedir (Yerasimos, ss. 66 - 67). 16 Kasım'da Heyeti Vekile kararıyla Karadeniz kıyılarında ilan edilen harp bölgesi kararı kaldırılmıştır (BCA, D: 94 - 17, F: 30.18.1.1., Yer: 4.37.14). Bu tarihe kadar kıyı bölgelerinden Sivas, Tokat, Yozgat, Çorum ve Karahisar-ı Şarki'ye toplam 63,844 Rum sevk edilmiştir (Yılmaz, 2010, s. 153). İç bölgelere sevk edilen Rumların toplandıkları merkezlere göre dağılımı şöyledir: 27,995 Rum Samsun, 14,000 Rum Amasya, 1,448 Rum Sivas, 4,910 Rum Ordu, 1,000 Rum Tokat, 571 Rum Çorum, 550 Rum Sinop ve 8,500 Rum Giresun (Balcloğlu, 2000, s. 120). Sevkiyat sırasında hükümetin olağanüstü dikkati ve sevk edilen Rumların her türlü ihtiyacının karşılanması emrine rağmen Yunan ve İngiliz kaynakları tarafından Rumların katledildiği propagandası yapılmıştır. Bu olumsuz propagandalara bizzat Mustafa Kemal Paşa 16 Haziran 1922'de Vakit Gazetesinde şöyle cevap vermiştir: “...Pontus Tehciri namı altında bir takım hayaller dedikodulara sermaye yapılıyor... Hükümet Türkiye aleyhinde şimdilik teşvik olunan Rumları askeri fikirlerden dolayı harp mıntıkasından uzaklaştırmıştır. Bu gibi tehcirler harp devam ettikçe zorunlu olarak tatbik olunacaktır” şeklinde cevap vermiş̧ir (Askeri Tarih Belgeleri Dergisi, Sayı: 13, s. 90).

Haziran 1921'de tenkil harekâtı şiddetlenmiş, bu tarihten sonra Rum çetelerle çatışmalar artarken pek çok çeteci de yakalanmıştır ( ATASE, ISH, Katalog 16A - 16B). Merkez Ordusu, 1921 yılı tenkil harekâtını 10,000 kişilik bir kuvvetle yürütmüştür. 7 Temmuz'da Dâhiliye Vekili Refet Bey, Karadeniz'deki tüm şehirlerin harp mıntıkası ilan edildiğini kamuoyuna duyurmuştur. 1921 yılı boyuna Karadeniz Bölgesi'nin hemen hemen tamamında devam eden harekât neticesinde, Ekim ayında "Rumların çekildiği, yerlerini terk ederek dağıldıkları" bildirilmiştir. Yine 1921 yılında Sivas İstiklâl Mahkemesi bir kararname ile Amasya - Samsun havalisinde görevlendirilmiştir (BCA 3.18.10). 1921 tenkil harekâtı sonucunda 3,877 çeteci öldürülmüş, 117 çete kampı yakılmış, buna karşılık 210 asker ve 704 halktan olmak üzere 914 şehit verilmiş ve 439 hane tahrip edilmiştir (CA, A:IV-15-a, D: 62, F: 9).

Pontus Sorunu bugün bilinenden çok daha büyük ve kapsamlı bir milli sorundu. Nitekim 1921 yılında yoğunlaşan tenkil harekâtına rağmen bölgedeki Pontus Sorunu tam olarak bitirilememiştir. Nitekim 12 Kasım 1922 tarihli bir kararnamede bölgede asayişin yeterince mükemmel hale gelmediği tespiti sonrasında Amasya Livası'nda 1,000, Tokat Liva'sında 500 silahlı askerin mevcut kuvvetlere ilave takibat için görevlendirilmelerine karar verilmiştir. ( BCA 5.28.11). Her şeye rağmen sorunun 1923 yıllarına değin uzandığı ve ciddi tedbirler gerektirdiği belgelerde görülmektedir. 8 Haziran 1923'de Erkan-ı Harbiye Reisi Fevzi Çakmak Paşa, şifreli bir mesaj ile İcra Vekilleri Hey'eti Riyaseti'ne başvurmuş, bölgedeki Rumların İslam ahalisinden silah almaya çalıştığı, bu nedenle İslam ahalisindeki silahların toplanması için müsaade istemiştir (BCA 030.10.00.00.109.724.9.3, BCA 
Mustafa Yahya METiNTAŞ | Mehmet KAYIRAN

030.10.00.00.109.724.9.4 - 109.724.9). İcra Vekilleri Hey'eti Riyaseti 19 Haziran 1923 tarihli şifreli mesajında "Şer-i İslam-ı Ahali" elindeki silahların derç edilmesinin Dahiliye Vekilliğince güvenlik nedeniyle uygun görülmediği bildirilmiştir (BCA 030.10.00.00.109.724.9.1 - 109.724.9).

1922 yılı başında Merkez Ordusu'nun er sayısı 20.000’e çıkarıldı. 6 Şubat 1923’e kadar güvenlik boyutu itibariyle Pontus tehlikesi yok edildi. 1920 - 1923 döneminde bölgedeki 10.886 çeteci etkisiz hale getirildi. Çatışmalar esnasında 11.188 isyancı öldü. Bu arada 1.817 Türk köylüsü Rum çetecilerce öldürüldü. 1921 yılı içinde 439 Türk köyü çeteciler tarafından yakılmıştı ( Çapa, 1993, s. 84). Geri kalan Rumlar 1923 yılı başında Yunanistan’a göç etti. Pontus Ayaklanması bastırıırken hukuk anlayışına uygun davranıldı. Başkomutan Mustafa Kemal Paşa, yakalanan isyancıların “Harp Divanları" tarafından yargılanmasına izin vermedi. Suçluların askeri birlikler tarafından katledildiği propagandasını bertaraf etmek amacıyla; isyancılar TBMM'nin olağanüstü mahkemeleri olan “ístiklal Mahkemeleri"nde yargılandı (Aybars, 2009, s. 117).

Pontus Sorunu boyunca, bölgede devletin idari görevlilerinin, Teşkilat'ı Milliye ve Müdafaa-i Hukuk Cemiyeti mensuplarının yoğun çabası ile gerçekten çok önemli bir milli mücadele yürütülmüştür. Bu mücadelede görev alan askeri ve idari personel ile cemiyetin önde gelen yöneticileri İstiklal Madalyası ile onurlandırılmıştır ( BCA 030.10.00.00.195.336.5.1 - 195.336.5, BCA 030.10.00.00.195.333.6.1 - 195.333.6). Mücadeledeki başarı bu tür ortamlarda bölgede görev yapan idari personelin devlete ve milli dâvaya sadakatleri ile resmi ve sivil kuruluşların işbirliğinin sonuç almada nedenli önemli olduğunu göstermektedir. Pontus Sorununun o dönemin çok zor şartlarında ve kısıtlı imkânlarıyla nasıl çözülebildiği Türkiye Cumhuriyeti için çok önemli ve ders alınacak bir süreçtir, bu nedenle konuyla ilgili yerel olayları inceleyen detaylı araştırmalara intiyaç olduğu açıktır.

\section{Sonuç}

Pontus sorunu, 19. Yüzyılın ortalarında Yunan bağımsızlık hareketiyle birlikte ortaya çıkmış ve Megalo İdea'nın bir uzantısı olarak Doğu Karadeniz kıyılarında Pontus adı altında bir Yunan - Rum devleti kurulması amacı çerçevesinde gelişmiştir. Yunan bağımsızlık hareketi içinde özellikle İngiltere, Fransa, Rusya ve ABD tarafından zaman zaman desteklenmiştir.

Pontus sorunu, I. Dünya Savaşı sırasında olgunlaşarak hem siyasi hem de çete faaliyetleri yönünden belirginlik kazanmıştır. Bu dönemde Doğu Karadeniz Bölgesi'ndeki Rum etnik kökenine bağlı çetecilik hareketi Rusya Hükümeti ve Rusya'daki Yunan siyasi memurlarının girişimiyle bir silahlı ayaklanmaya dönüştürülmüştür. Bu amaçla Batum'da teşkil edilen gizli komitelerle bölgeye silah, cephane ve mühimmat gönderilmiştir. Mondros Mütarekesinden sonra da Pontus Sorunu'nun Paris Barış Konferansı'nın gündemine sokularak konu ile ilgili diplomatik çabaların ağırlık merkezinin Avrupa'ya kayması sağlanmıştır. Mütareke döneminde Batı Anadolu'daki Yunan ilerlemesine paralel olarak, Samsun başta olmak üzere, Doğu Karadeniz Bölgesi'nde Türk - İslam ahaliye yönelik Pontus çetelerinin giderek artan ciddi bir tehdidi söz konusu olmuştur. 
Diplomatik faaliyetler dışında bölgedeki Pontusçulukla ilgili çalışmaları şöyle özetleyebiliriz:

1 - Helenleştirme siyaseti ve Yunan propagandası

2-Rum göçmenler

3-Rum çeteleri

4-Türkleri ekonomik olarak zayıflatma çalışmaları

Ankara'da kurulan TBMM Hükümeti, 1920 yılı başlarından itibaren bir yandan Milli Mücadeleyi sürdürürken diğer taraftan da Pontus sorunu ile uğraşmak ve ciddi tedbirler almak zorunda kalmıştır. Bağımsızlık Savaşı yıllarında Pontus çetelerinin isyanlarını bastırmak üzere Merkez Ordusu Komutanlığı kurulmuş; ayaklanmalar 1923 yılının ilk aylarında tamamen bastırılabilmiştir. Milli Mücadele sonrasında Pontus Sorunu Lozan Konferansında alınan karar doğrultusunda Türk ve Rum ahalinin mübadele edilmesi ile çözüme kavuşturulmuştur.

Pontus sorununun, askeri veçhesi Milli Mücadele sırasında TBMM'ye bağlı güçler tarafından çözümlense de siyasi, tarihi, kültürel bazı talepler halinde etkisi günümüze kadar devam etmekte; bu sebeple de Türkiye'nin gelecekte izleyeceği politikalarının oluşturulması açısından ders verici özellikler taşımaktadır. Bu araştırmada Pontus Sorunu'nun tarihsel gelişimi mevcut kaynaklar ve arşiv belgeleri ışığında incelenmiştir.

Bu suni sorun yunanistan'ın ve batılı emperyalist devletlerin siyasi, askeri, dini, etnik ve kültürel kışkırtmalarının bir neticesi olarak geçmişte ve günümüzde Türkleri dünya kamuoyu önünde zor duruma düşürmek için başvurdukları bir araçtır.

Patrikhane, misyonerler ve yabancı okullar tarafından desteklenen Pontus projesi, 19. Yüzyıl boyunca Osmanlı Devleti'ni uğraştıran azınlık isyanlarının bir parçasıdır. Merzifon'daki Amerikan Koleji öğretim elemanlarının çalışmalarıyla 1904 yııında kurulan "Pontus Cemiyeti", iç ve dış desteklerle Anadolu'da yaygın bir örgüt haline getirilmiştir. Ayrıca "Mukaddes Anadolu Rum Cemiyeti" adıyla terörcü ikinci bir cemiyet daha kurulmuştur.

Birinci Dünya Savaşı sırasında Yunanistan ve İtilaf Devletleri yararına casusluk yapan Pontusçuların amacl; merkezi Samsun olan Batum'dan İnebolu'ya kadar uzanan ve Kastamonu, Yozgat, Sivas, Tokat, amasya, Çorum, Gümüşhane, Erzincan gibi yerleri de içine alan topraklar üzerinde bir Pontus Devleti kurmaktı. Rusların Trabzon'u işgaline yardım eden Pontusçular, serbestçe silahlandılar... Paris Barış konfernası sırasında yoğun bir propaganda başlatan Rum azınlık, Samsun ve yöresinde Müslümanların Hristiyanları katlettikleri tarihi yalanlarını ileri sürdüler. Bu yerlerde çeteler oluşturan Rumlar, Mondros Mütarekesi'nden sonra başta Yunanistan olmak üzere İngiltere'nin desteği ile bölgedeki Türkleri katletmeyi sürdürdüler. Türkler de kendilerini korumak için örgütlenmeye başladılar. Türklerin bölgede kurdukları grupların en önemlisi “Topal Osman Ağa Çetesi"dir...

Pontusçu faaliyetleri önlemek amacıyla Milli Mücadele döneminde çeşitli önlemler alındı. Trabzon Muhafaza-yı Hukuk-u Milliye Cemiyeti'nin çalışmaları ve başta İstiklal olmak üzere halkı 
bilinçlernirmeye yönelik yayın organlarının çabaları ile halkın milli birlik ve bütünlük davası uğrunda vermiş oldukları büyük mücadeleye katılımları arttırıldı. Türkiye Cumhuriyeti kurulduğu zaman hem Pontus isyanı son bulmuş, hem de Lozan'da imzalanan Türk - Rum Ahali Mübadelesi Sözleşmesi gereğince geride kalan Rumlar Yunanistan'a gittiğinden, Karadeniz Bölgesi homojen bir yapıya kavuşmuştu.

Mustafa Kemal Atatürk'ün önderliğinde yürütülen Bağımsızlık Savaşı'nın zaferle sonuçlandırılması ve lozan Barış Antlaşması'nın imzalanması ile Pontus Sorunu fiilen ve hukuken sona ermiştir. Ancak 1940'lı yıllardan itibaren Pontus sorunu yeniden uluslararası alana taşınmaya başlanmıştır. Günümüzde ise başta Yunanistan olmak üzere; Türkiye Cumhuriyeti'ni siyasi açıdan yıpratmak ve uğraştırmak amacıyla ABD, Kanada, İngiltere ve Fransa gibi ülkelerde “soykırım iddiaları"nı gündeme taşıyan, hatta Türkiye'den toprak talebinde bulunan onlarca dernek kurulmuştur. Yunan Parlementosu'nun 1994 yılında aldığı kararla 19 Mayıs 1919'u “Pontus Soykırımı́nı Anma Günü” ilan etmesinden sonra bu sözde soykııımı türkiye'nin tanıması yönünde girişimler başlatılmıştır... Hatta bölgede yaşayan Türk vatandaşlarının ayrımcılığa tabi tutulduklarını ileri süren raporlar yayınlanmakta ve "Pontus Sorunu" nu diriltmek amacıyla çeşitli gayretler sarf edilmektedir. Bu tür faaliyetlerin boşa çıkarılması için de hiç kuşkusuz bu meselenin tarihsel arka planının bilinmesini sağlayıcı pek çok araştırmanın yapılması gerekmektedir. Zira bu sorunu gündeme taşıyan ve tarihi olayları tahrif ederek dünyaya aktaran yüzlerce araştırma Türkiye karşıtları tarafından yayınlanmaktadir.

\section{Kaynaklar}

\section{Arşiv Belgeleri ve Basılı Belgesel Kaynaklar}

ATASE, KLS: 198, DS: 101, FH: 85.

ATASE, ISH, K: 314, G: 129.

ATASE, ISH, K: 89, G: 327.

ATASE, ISH, K: 183, G: 85.

ATASE, ISH, K: 368, G: 38.

ATASE, ISH, K: 605, D: 173, F: 126.

ATASE, ISH, K: 635, G: 205.

ATASE, ISH, K: 16A-16B.

ATASE, ISH, K: 1112, G: 86.

ATASE, iSH, 18C.

ATASE, ISH, K: 88, G: 322. 
ATASE, ISH, K: 633, G: 35.

BCA, D: $94-17, F:$ 30.18.1.1. Yer: 4.37.14.

BCA 3.18.10.

BCA 5.28.11.

BCA 030.10.00.00.109.724.9.3.

BCA 030.10.00.00.109.724.9.4-109.724.9.

BCA 030.10.00.00.109.724.9.1-109.724.9.

BCA 030.10.00.00.109.724.9.2-109.724.9.

BCA 030.10.00.00.195.336.5.1-195.336.5.

BCA, 250.690.5.

BCA 030_10_00_00.

BOA, DH. KMSi D: 49-2, V:24-3.

BOA, DH. EUM. THR, D: 11, V: 20.

BCA, A:IV-15-a, D: 62, F: 9.

TBMM Gizli Celse Zabitları, (1985), Cilt III, Ankara.

TBMM Zabıt Ceridesi (1958), 15. Cilt, Ankara: TBMM Basımevi.

Makaleler ve Kitaplar

Aralov, S. i. , (2008). Bir Sovyet Diplomatının Türkiye Hatıraları, i̇stanbul: Türkiye İş Bankası Kültür Yayınları.

Arseven, C. E. , (1989). Eski Istanbul, i̇stanbul: İstanbul kütüphanesi Yayınları.

Atatürk M. K. , (1973). Nutuk, Cilt: 1-2, ìstanbul: MEB Yayınları.

Aybars E., (2009). İstiklal Mahkemeleri, Ankara: Araç Kitapevi.

Balcıoğlu, M. , (2000). iki Isyan 'Koşgiri - Pontus - Bir Paşa' Nurettin Paşa, ístanbul: Ebabil Yayıncılik.

Bayar, C. , (1967). Ben'de Yazdım, i̇stanbul: Baha Matbaası.

Çapa, M. , (1993). Pontus Meselesi - Trabzon ve Giresun'da Milli Mücadele, Ankara: Türk Kültürü Araştırmaları Enstitüsü Yayınları.

Çiçek, R. , (2000). Merzifon Amerikan Koleji ve Pontus Meselesindeki Yeri, 19 Mayıs ve Milli Mücadele'de Samsun Sempozyumu, Samsun. 
Mustafa Yahya METiNTAŞ | Mehmet KAYIRAN

Doğanay, R. , (2001). Milli Mücadele'de Karadeniz, Ankara: Atatürk Araştırma Merkezi

Esegin, K. , (1969). Milli Mücadele'de Hıyanet Yarışı, Ankara.

Gedikli, Y. , (2002). Pontus Meselesi, İstanbul: Bilge Karınca Yayınları.

Genelkurmay Başkanlığı, (1984). Türk Silahlı Kuvvetleri Tarihi: TBMMDönemi, (23 Nisan 1920 - 29 Ekim 1923), C. IV, Ankara: Genelkurmay Basımevi.

Genelkurmay Başkanlığı, (1974). Türk Istiklal Harbi, Cilt 6, , Ankara: Genelkurmay Basımevi.

Genelkurmay Başkanlığı, (1974). Istiklal Harbinde Ayaklanmalar, Ankara: Genelkurmay Başkanlığı Yayınları.

Genelkurmay Başkanlığı, (1975). Türk Istiklal Harbi: Idari Faaliyetler, C. 8, Ankara: Genelkurmay Basımevi.

Genelkurmay Başkanlığı, (2009). Arşiv Belgeleriyle Rum Faaliyetleri, , Ankara: Genelkurmay Basımevi.

Goloğlu, M. , (1973). Anadolu'nun Milli Devleti Pontos, Ankara: Goloğlu Yayınları.

Gökbilgin, M. T. , (1959). Milli Mücadele Başlarken, Ankara.

Gülbadi, A. , (2008). Anadolu'da Yabancı Okullar ve Pontusçuluk, Pontus Sorunu, Trabzon.

Güler, A. , (1988). İsyan Yıllarında Yunan Teşkilatları, Ankara.

Güzel, A. (2006). Dünden Bugüne Yunanistan'ın Pontus Hedefi. İstanbul.

Jaeschke, G. , (1991). Kurtuluş Savaşı Ile ilgili Ingiliz Belgeleri, Ankara: TTK Basımevi.

Karabekir, K. , (2008). Istiklal Harbimiz, İstanbul: Yapı Kredi Yayınları.

Kul, Ö., (2008). Pontus Dedikleri, İstanbul: Togan Yayıncılık.

Kurt, Y. , (1995). Pontus Meselesi, Ankara: TBMM Yayınları.

Yazıcı, N. , (2003). Milli Mücadele'de Pontus'çu Faaliyetler (1918 - 1922), Konya: Çizgi Kitapevi.

Okyar, F. , (1980). Üç Devirde Bir Adam, İstanbul: Tercüman Yayınları.

Özel, S. , (1991). Milli Mücadele'de Trabzon, Ankara: TTK Basımevi.

Pehlivanlı H., (1999). Tarih Perspektifi İçerisinde Pontus Olayı: Yakın Tarihimize ve Günümüze Etkileri, Pontus Meselesi ve Yunanistan'ın Politikası, Ankara: ATAM Yayınları.

Sarınay, Y. , (1999). Pontus Meselesi ve Yunanistan'ın Politikası, Ankara: ATAM Yayınları.

Sertoğlu, M., (1982). “Pontus” Meselesine Ait Bazı Vesikalar, Türk Kültürü, Sayı: 231. 
Sonyel S. R. , (1995). Türk Kurtuluş Savaşı ve Dış Politika, Cilt I, Ankara: TTK Basımevi.

Tansel, S. , (1991). Mondros'tan Mudanya'ya Kadar, Cilt I, İstanbul: MEB Yayınları.

Turan, M., (1999). Yunan Mezalimi (1919-1923), Ankara: Atatürk Araştırma Merkezi Yayınları.

Turan, Ş., (1991). Türk Devrim Tarihi 1. Kitap: Imparatorluğunun Çöküşünden Ulusal Direnişe, Ankara: Bilgi Yayınevi.

Yılmaz, H. , (2010). Arşiv Belgeleri Işığında Pontus Meselesi, Ankara: ATAM Yayınları. 